\title{
EFIKASI DIRI, DUKUNGAN SOSIAL KELUARGA DAN SELF REGULATED LEARNING PADA SISWA KELAS VIII
}

\author{
Nobelina Adicondro \& Alfi Purnamasari \\ Fakultas Psikologi \\ Universitas Ahmad Dahlan \\ Jalan Kapas No. 9 Yogyakarta \\ alfi_purnamasari@yahoo.com.
}

\begin{abstract}
The purposes of this study were to find out (1) the relation between self efficacy, family social support and self regulated learning (2) the relation between self efficacy and self regulated learning (3) the relation between family social support and self regulated learning. The populations of the study were students of 8th grade students at SMP Muhammadiyah. The technique sampling was cluster random sampling. The study used Self Efficacy Scale, Family Social Support Scale and Self Regulated Learning Scale to collect data about self efficacy, family social support and self regulated learning. The data were analized by regression analysis. The results show that (1) there is very significantly positive correlation between self efficacy, family social support and self efficacy $(r=0,837, p=0,000)$, (2) there is very significantly positive correlation between self efficacy and self regulated learning $(r=0,836, p=0,000)$, (3) there is very significantly positive correlation between family social support and self regulated learning $(\mathrm{r}=0,418, \mathrm{p}=0,002)$.
\end{abstract}

Keyword: Self Efficacy, Self Regulated Learning, Social Support Family.

\begin{abstract}
Abstrak
Penelitian ini dilakukan dengan tujuan untuk (1) Mengetahui hubungan antara efikasi diri dan dukungan sosial keluarga dengan self regulated learning (2) Mengetahui hubungan antara efikasi diri dengan self regulated learning (3) Mengetahui hubungan antara dukungan sosial keluarga dengan self regulated learning. Populasi dalam penelitian ini adalah siswa Kelas VIII SMP Muhammadiyah. Total sampel penelitian berjumlah 62 siswa yang dipilih dengan tekhnik cluster random sampling. Data di dalam
\end{abstract}


penelitian ini dikumpulkan dengan menggunakan Skala Self Regulated Learning, Skala Efikasi Diri dan Skala Dukungan Sosial Keluarga. Data kemudian dianalisis dengan menggunakan teknik analisis regresi. Hasil analisis data menunjukkan: (1) Ada hubungan positif yang sangat signifikan antara efikasi diri dan dukungan sosial keluarga dengan self regulated learning $(\mathrm{r}=0,837, \mathrm{p}=0,000)(2)$. Ada hubungan positif yang sangat signifikan antara efikasi diri dengan self regulated learning $(r=0,836$ $\mathrm{p}=0,000)$. (3). Ada hubungan positif yang sangat signifikan antara dukungan social keluarga dengan self regulated learning $(\mathrm{r}=0,418 \mathrm{p}=0,002)$.

Kata kunci: Efikasi Diri, Self Regulated Learning, Dukungan Sosial Keluarga.

\section{Pendahuluan}

Ada komponen-komponen penting yang harus diperhatikan dalam suatu proses pendidikan yaitu, pendidik, peserta didik, sarana dan prasarana, lingkungan pendidikan, dan kurikulum sebagai materi ajar untuk peserta didik. Komponen komponen ini memegang peranan yang sangat penting dalam suatu proses pendidikan sehingga dapat menghasilkan peserta didik yang berguna bagi bangsa dan negara. Hal ini merupakan tujuan penting para siswa untuk mengikuti suatu proses belajar di sekolahnya.

Menurut Winne (Santrock, 2007) self regulated learning adalah kemampuan untuk memunculkan dan memonitor sendiri pikiran, perasaan, dan perilaku untuk mencapai suatu tujuan. Tujuan ini bisa jadi berupa tujuan akademik (meningkatkan pemahaman dalam membaca, menjadi penulis yang baik, belajar perkalian, mengajukan pertanyaan yang relevan), atau tujuan sosioemosional (mengontrol kemarahan, belajar akrab dengan teman sebaya). Pelajar regulasi diri memiliki karakteristik bertujuan memperluas pengetahuan dan menjaga motivasi, menyadari keadaan emosi mereka dan punya strategi untuk mengelola emosinya, secara periodik memonitor kemajuan ke arah tujuannya, menyesuaikan atau memperbaiki strategi berdasarkan kemajuan yang mereka buat, dan mengevaluasi halangan yang mungkin muncul dan melakukan adaptasi yang diperlukan. Self regulated learning adalah proses aktif dan konstruktif siswa dalam menetapkan tujuan untuk proses belajarnya dan berusaha untuk memonitor, meregulasi, dan mengontrol kognisi, motivasi, dan perilaku, yang kemudian semuanya diarahkan dan didorong oleh tujuan dan 
mengutamakan konteks lingkungan. Siswa yang mempunyai self regulated learning tinggi adalah siswa yang secara metakognitif, motivasional, dan behavioral merupakan peserta aktif dalam proses belajar.

Siswa diharapkan memiliki self regulated learning yang tinggi. Apabila para siswa memiliki self regulated learning yang rendah akan mengakibatkan kesulitan dalam menerima materi pelajaran sehing ga hasil belajar mereka menjadi tidak optimal. Selain itu, hal tersebut juga dapat berdampak pada ketidaklulusan, karena apabila sampai kelas IX tidak ada perubahan dalam hal mereka belajar maka siswa akan sulit mencapai standar kelulusan dari pemerintah yang setiap tahunnya naik.

Zimmerman dkk (Santrock, 2007) menyimpulkan bahwa ada tiga aspek dalam self regulated learning, adalah metakognisi, motivasi, dan perilaku. Metakognisi adalah kemampuan individu dalam merencanakan, mengorganisasikan atau mengatur, menginstruksikan diri, memonitor dan melakukan evaluasi dalam aktivitas belajar. Motivasi merupakan fungsi dari kebutuhan dasar untuk mengontrol dan berkaitan dengan perasaan kompetensi yang dimiliki setiap individu. Perilaku merupakan upaya individu untuk mengatur diri, menyeleksi, dan memanfaatkan lingkungan maupun menciptakan lingkungan yang mendukung aktivitas belajar.

Menurut Zimmerman (1990) dalam teori sosial kognitif terdapat tiga hal yang mempengaruhi seseorang sehingga melakukan self regulated learning, yakni individu, perilaku dan lingkungan. Faktor individu meliputi pengetahuan, tujuan yang ingin dicapai, kemampuan metakognisi serta efikasi diri. Faktor perilaku meliputi behavior self reaction, personal self reaction serta environment self reaction. Sedangkan faktor lingkungan dapat berupa lingkungan fisik maupun lingkungan sosial, baik lingkungan keluarga, lingkungan sekolah, lingkungan pergaulan dan lain sebagainya. Salah satu yang dapat mempengaruhi self regulated learning dalam faktor individu adalah efikasi diri dan faktor lingkungan di antaranya adalah dukungan sosial dari keluarga.

Menurut Bandura (1977) efikasi diri adalah keyakinan seorang individu mengenai kemampuannya dalam mengorganisasi dan menyelesaikan suatu tugas yang diperlukan untuk mencapai hasil tertentu. Efikasi diri yakni keyakinan bahwa seseorang bisa menguasai situasi dan mendapatkan hasil positif. Bandura (Santrock, 2007) mengatakan bahwa efikasi diri berpengaruh besar terhadap perilaku. Misalnya, seorang murid yang efikasi diri-nya rendah mungkin tidak mau berusaha belajar untuk mengerjakan ujian karena tidak percaya bahwa belajar akan bisa membantunya mengerjakan soal.

Bandura (1977) mengemukakan beberapa dimensi dari efikasi diri, yaitu magnitude, generality, dan strength. Magnitude, berkaitan dengan tingkat kesulitan 
suatu tugas yang dilakukan. Generality, berkaitan dengan bidang tugas, seberapa luas individu mempunyai keyakinan dalam melaksanakan tugas-tugas. Strength, berkaitan dengan kuat lemahnya keyakinan seorang individu.

Efikasi diri menurut Alwisol, (2005) dapat diperoleh, diubah, ditingkatkan atau diturunkan, melalui salah satu atau kombinasi empat sumber, yakni pengalaman menguasai sesuatu prestasi (performance accomplishment), pengalaman vikarius (vicarious experiences), persuasi sosial (social persuation) dan pembangkitan emosi (emotional/ physiological states). Pengalaman performansi adalah prestasi yang pernah dicapai pada masa yang telah lalu. Pengalaman vikarius diperoleh melalui model sosial. Persuasi sosial adalah rasa percaya kepada pemberi persuasi, dan sifat realistik dari apa yang dipersuasikan

Efikasi diri diduga akan mempengaruhi self regulated learning. Orang yang memiliki efikasi diri yang tinggi akan memiliki keyakinan mengenai kemampuannya dalam mengorganisasi dan menyelesaikan suatu tugas yang diperlukan untuk mencapai hasil tertentu dalam berbagai bentuk dan tingkat kesulitan. Hal ini berdampak self regulated learning juga akan tinggi. Ia akan mampu mengelola mengelola secara efektif pengalaman belajarnya sendiri di dalam berbagai cara sehingga mencapai hasil belajar yang optimal. Efikasi diri yang rendah akan sangat mempengaruhi seseorang dalam menyelesaikan tugasnya untuk mencapai hasil tertentu. Hal ini dapat dikaitkan dengan kurangnya informasi tentang kemampuan para siswa untuk yakin pada dirinya sendiri dalam mengerjakan tugas yang diberikan kepada mereka.

Selain efikasi diri, faktor lain yang diduga dapat mempengaruhi self regulated learning adalah dukungan sosial. Dukungan sosial termasuk sebagai faktor lingkungan. Baron dan Byrne (2005) menyatakan bahwa dukungan sosial adalah kenyamanan secara fisik \& psikologis yang diberikan oleh teman/anggota keluarga. Dukungan sosial juga dapat dilihat dari banyaknya kontak sosial yang terjadi atau yang dilakukan individu dalam menjalin hubungan dengan sumber-sumber yang ada di lingkungan. Penelitian ini lebih menekankan pada dukungan sosial yang bersumber dari keluarga.

House (Smet, 1994) menyatakan empat aspek dukungan sosial yaitu, dukungan emosional, penghargaan, instrumental, dan informatif. Menurut Johnson \& Johnson (1991) dukungan sosial berasal dari orang-orang penting yang dekat (significant others) bagi individu yang membutuhkan bantuan misalnya di sekolah seperti guru dan teman-temannya. Penulis menekankan pada dukungan sosial keluarga yang akan mempengaruhi self regulated learning anak dalam proses belajar mereka. Menurut Johnson \& Johnson (1991) ada empat manfaat dukungan sosial, yaitu dukungan sosial dihubungkan dengan pekerjaan akan meningkatkan produktivitas, meningkatkan 
kesejahteraan psikologis dan penyesuaian diri dengan memberikan rasa memiliki, memperjelas identitas diri, menambah harga diri serta mengurangi stres, meningkatkan dan memelihara kesehatan fisik serta pengelolaan terhadap stress \& tekanan.

Dukungan sosial menjadi hal yang diduga dapat mempengaruhi self regulated learning. Dukungan sosial dari keluarganya tinggi diduga akan meningkatkan self regulated learning. Orang yang mendapatkan dukungan sosial keluarga yang tinggi maka akan banyak mendapatkan dukungan emosional, penghargaan, instrumental, dan informatif dari keluarga. Apabila dukungan emosional tinggi, individu akan merasa mendapatkan dorongan yang tinggi dari anggota keluarga. Apabila penghargaan untuk individu tersebut besar, maka akan meningkatkan kepercayaan diri. Apabila individu memperoleh dukungan instrumental, akan merasa dirinya mendapat fasilitas yang memadai dari keluarga. Apabila individu memperoleh dukungan informatif yang banyak, akan inidvidu itu merasa memperoleh perhatian dan pngetahuan. Hal tersebut berdampak pada self regulated learning individu tersebut menjadi tinggi karena individu mampu mengelola secara efektif pengalaman belajarnya sendiri di dalam berbagai cara sehingga mencapai hasil belajar yang optimal.

\section{Metode Penelitian}

Populasi dalam penelitian ini adalah Siswa/siswi Kelas VIII SMP Muhammadiyah yang berusia 11-17 tahun yang seluruhnya berjumlah 154 anak. Teknik sampling menggunakan cluster random sampling dan terpilih 62 siswa dari 2 kelas sebagai sampel penelitian.

Alat ukur yang digunakan di dalam penelitian ini adalah Skala Efikasi Diri, Skala Dukungan Sosial Keluarga serta Skala Self Regulated Learning. Skala Self regulated learning Learning terdiri dari 27 aitem dan disusun berdasarkan teori yang dikemukakan Zimmerman (1990) tentang aspek-aspek SelfRegulated Learning yang terdiri dari metakognisi, motivasi dan perilaku. Skala Efikasi Diri berjumlah 33 aitem dan disusun berdasarkan teori tentang dimensi-dimensi efikasi diri yang dikemukakan oleh Bandura (1997) yaitu magnitude, generality, dan strength. Aitem yang digunakan dalam Skala Efikasi Diri. Skala Dukungan Sosial Keluarga berjumlah 36 aitem dan disusun menggunakan teori yang dikemukakan House (Smet, 1994) yang terdiri dari aspek dukungan emosi, penghargaan, informasi dan instrumen. 


\section{Hasil dan Pembahasan}

Data penelitian meliputi data self regulated learning, data efikasi diri dan data dukungan sosial keluarga. Sampel yang diambil data dalam penelitian ini adalah 62 subjek siswa kelas VIII SMP Muhammadiyah.

Berdasarkan hasil kategorisasi skor variabel self regulated learning, diperoleh informasi bahwa dari 62 subjek penelitian terdapat $2(3,23 \%)$ subjek penelitian yang berada pada kategori rendah, $50(80,65 \%)$ subjek penelitian berada pada kategori sedang sedang dan $10(16,13 \%)$ subjek penelitian berada pada kategori tinggi.

Berdasarkan hasil kategorisasi skor variabel efikasi diri, diperoleh informasi bahwa dari 62 subjek penelitian terdapat $2(3,23 \%)$ subjek penelitian yang berada pada kategori rendah, $54(67,74 \%)$ subjek penelitian berada pada kategori sedang sedang dan $19(29,03 \%)$ subjek penelitian berada pada kategori tinggi.

Berdasarkan hasil kategorisasi skor variabel dukungan sosial keluarga, diperoleh informasi bahwa dari 62 subjek penelitian terdapat $1(1,61 \%)$ subjek penelitian yang berada pada kategori rendah, $32(51,61 \%)$ subjek penelitian berada pada kategori sedang sedang dan $29(46,77 \%)$ subjek penelitian berada pada kategori tinggi.

Hasil analisis data menunjukkan bahwa koefisien korelasi ganda antara efikasi diri dan dukungan sosial keluarga dengan self regulated learning adalah $R=0,837$ dengan taraf signifikansi 0,000 ( $p<0,01$ ). Hasil tersebut menunjukkan bahwa efikasi diri dan dukungan sosial keluarga memiliki hubungan yang sangat signifikan dengan self regulated learning. Berdasarkan hasil penelitian ini dapat diketahui bahwa ada dua faktor internal (dalam diri individu) yang menentukan atau mempengaruhi self regulated learning adalah efikasi diri dan dukungan sosial keluarga.

Efikasi diri adalah proses kognitif yang mempengaruhi motivasi seseorang untuk berperilaku. Seberapa baik seseorang dapat menentukan atau memastikan terpenuhinya motif mengarah pada tindakan yang diharapkan sesuai situasi yang dihadapi. Keyakinan akan seluruh kemampuan ini meliputi kepercayaan diri, kemampuan menyesuaikan diri, kemampuan kognitif, kecerdasan, dan motivasi untuk bertindak pada situasi yang penuh tekanan. Efikasi diri akan berkembang berangsurangsur secara terus menerus sejalan dengan meningkatnya kemampuan dan bertambahnya pengalaman-pengalaman yang berkaitan (Bandura, 1997). Efikasi diri ini sangat menentukan seberapa besar keyakinan mengenaikemampuan yang dimiliki oleh setiap individu untuk melakukan proses belajarnya sehingga dapat mencapai hasil belajar yang optimal. Individu yang memiliki efikasi diri yang tinggi akan dengan 
baik mengatur dirinya untuk belajar. Ada keyakinan dalam dirinya bahwa ia akan mampu menyelesaikan tugas sesulit apapun saat belajar, keyakinan bahwa ia mampu menyelesaikan berbagai macam tugas serta usaha yang keras untuk menyelesaikan semua tugas. Hal tersebut akan dapat mendorong individu untuk dapat merencanakan aktivitas belajarnya, berusaha untuk memonitornya serta memanipulasi lingkungan sedemikian rupa guna mendukung aktivitas belajarnya. Dengan demikian dapat diketahui apabila efikasi diri yang dimiliki individu rendah, dapat menyebabkan hambatan dalam proses belajarnya meskipun individu tersebut memiliki potensi yang besar. Efikasi diri yang tinggi menyebabkan munculnya self regulated learning yang jugatinggi.

Faktor internal lainnya yang mampu mempengaruhi self regulated learning adalah dukungan sosial keluarga yang memiliki peranan cukup penting karena keluarga merupakan orang yang terdekat dengan individu. Apabila individu mendapatkan dukungan emosi dari keluarganya, saat menghadapi rintangan dalam belajar maka anak akan mendapatkan dukungan dari keluarganya sehingga ia tetap merasa lebih percaya diri dan tetap mampu merencanakan dan mengontrol kegiatan belajarnya serta memanfaatkan lingkungannya. Saat anak diberikan dukungan penghargan yang sifatnya positif, misalnya dalam bentuk pujian dari keluarganya anak akan merasa dirinya cukup berharga sehingga saat belajar ia memiliki dorongan untuk mengatur dan memonitor kegiatan belajarnya dan menyeleksi lingkungan yang kondusif untuk pross belajar. Dukungan informasi yang diberikan oleh keluarga juga akan membantu anak untuk mendapatkan informasi baik tentang cara belajar yang baik maupun nasehat dari keluarga tentang permasalahan pribadi yang dihadapi oleh anak, sehingga anak tetap mampu mengontrol aktivitas belajarnya, membuat rencana dalam belajar serta menciptakan lingkungan yang kondusif untuk belajar. Sedangkan dukungan yang berupa materi / instrumental dapat terlihat dari orang tua yang berusaha untuk menyiapkan peralatan dan sarana belajar yang baik untuk anak, sehingga anak memiliki motivasi untuk mempersiapkan dan mengatur aktivitas belajarnya serta memanfaatkan lingkungannya supaya dapat belajar dengan efektif. Dengan demikian dapat disimpulkan bahwa semakin tinggi dukungan sosial yang diberikan oleh keluarga, maka akan semakin tinggi self regulated learning yang dimiliki.

Apabila kedua faktor, yaitu efikasi diri serta dukungan sosial keluarga dimiliki oleh individu maka keduanya secara bersama-sama akan dapat meningkat self regulated learning seseorang. Karena motivasi individu untuk merencanakan, memonitor dan mengontrol kegiatan belajarnya muncul dari motivasi yang sifatnya internal maupun eksternal. 
Hasil analisis (product moment) antara variabel efikasi diri dengan self regulated learning menunjukkan koefisien korelasi antara efikasi diri dan self regulated learning adalah $\mathrm{r}=0,836$ dengan taraf signifikansi $0,000(\mathrm{p}<0,01)$ yang berarti semakin tinggi efikasi diri maka self regulated learning semakin tinggi dan semakin rendah efikasi diri maka self regulated learning semakin rendah. Siswa yang memiliki efikasi diri yang tinggi akan memiliki keyakinan saat mengerjakan tugas termasuk tugas yang sulit serta merasa mampu melaksanakan berbagai macam tugas sehingga lebih mampu merencanakan, mengorganisasikan atau mengatur, menginstruksikan diri, memonitor serta melakukan evaluasi dalam aktivitas belajar. Selain itu ia juga mampu untuk mengatur diri, menyeleksi, dan memanfaatkan lingkungan maupun menciptakan lingkungan yang mendukung aktivitas belajar sehingga self regulated learning menjadi tinggi. Ia akan mampu mengelola secara efektif pengalaman belajarnya sendiri di dalam berbagai cara sehingga mencapai hasil belajar yang optimal. Efikasi diri yang rendah juga akan sangat mempengaruhi seseorang dalam menyelesaikan tugasnya untuk mencapai hasil tertentu. Hal ini dapat dikaitkan dengan kurangnya informasi tentang kemampuan para siswa untuk yakin pada dirinya sendiri dalam mengerjakan tugas yang diberikan kepada mereka.

Selanjutnya, hasil analisis dukungan sosial keluarga dengan self regulated learning menunjukkan bahwa koefisien korelasi antara self regulated learning dengan dukungan sosial keluarga adalah $\mathrm{r}=0,418$ dengan taraf signifikansi $\mathrm{p}=$ $0,002(p<0,01)$ yang berarti semakin tinggi dukungan sosial keluarga maka self regulated learning semakin tinggi, dan semakin rendah dukungan sosial keluarga maka self regulated learning semakin rendah.

Menurut Hurlock (2001) dukungan dari keluarga yang berupa penerimaan, perhatian dan rasa percaya tersebut akan meningkatkan kebahagiaan dalam diri remaja. Kebahagiaan yang diperoleh remaja menyebabkan remaja termotivasi untuk terus berusaha mencapai tujuannya. Remaja juga mempunyai rasa percaya diri dalam menyelesaikan tugas yang dihadapi. Jadi dukungan sosial dari keluarga akan membantu remaja dalam menyelesaikan suatu masalah. Oleh sebab itu, dapat diketahui bahwa dukungan sosial dari keluarga memiliki peranan yang cukup penting untuk individu dalam mengatur proses belajarnya. Individu memerlukan bantuan untuk mendukung belajarnya agar dapat mencapai hasil yang optimal dengan arahan dari keluarga, pujian yang membangkitkan semangat, kasih sayang dan fasilitas yang memadai. Apabila dukungan sosial dari keluarga yang diterima oleh individu yang bersangkutan rendah, hal ini dapat menyebabkan terhambatnya kemampuan individu untuk mencapai suatu proses belajar yang optimal.

Dukungan sosial dari keluarganya tinggi akan meningkatkan self regulated 
learning. Orang yang mendapatkan dukungan sosial keluarga yang tinggi maka akan banyak mendapatkan dukungan emosional, penghargaan, instrumental, dan informatif darikeluarga. Apabila dukungan emosional tinggi, individu akan mendapatkan motivasi yang tinggi dari anggota keluarga. Apabila penghargaan untuk individu tersebut besar, maka akan mendapatkan pujian. Apabila individu memperoleh instrument, akan mendapatkan fasilitas yang memadai dari keluarga. Apabila individu memperoleh informatif yang banyak, akan memperoleh nasihat sehingga individu tersebut menjadi lebih percaya diri. Hal tersebut berdampak self regulated learning individu tersebut menjadi tinggi karena individu mampu mengelola secara efektif pengalaman belajarnya sendiri di dalam berbagai cara sehingga mencapai hasil belajar yang optimal.

Kategorisasi subyek menunjukan bahwa sebanyak 50 subjek penelitian atau $80,65 \%$ dari 62 subjek penelitian memiliki tingkat self regulated learning yang sedang. Hal ini menunjukan bahwa pada umumnya subyek cukup memiliki kemampuan untuk mengelola dirinya secara aktif untuk memperoleh pengetahuan dalam proses belajarnya. Hal ini dapat disebabkan karena individu menggunakan kemampuannya untuk belajar meskipun belum secara optimal. Hal ini dapat disebabkan karena pengetahuan individu yang semakin banyak dan beragam, adanya target tinggi yang ingin dicapai, menggunakan strategi belajar, dan adanya dukungan sosial dari orang-orang terdekatnya.

Kategorisasi efikasi diri menunjukan bahwa sebanyak 42 subjek penelitian atau $67,74 \%$ dari 62 subjek penelitian memiliki efikasi diri yang sedang. Hal ini menunjukkan bahwa pada umumnya subyek cukup memiliki keyakinan mengenai kemampuan dirinya dalam belajar untuk mencapai tujuan dan mengatasi hambatan. Individu yang memiliki keyakinan mengenai kemampuannya dapat disebabkan karena individu bekerja lebih keras dan tekun dalam mengerjakan tugas yang diberikan ditengah kesulitan. Individu lebih menyukai kerja sendiri tanpa bantuan orang lain. Selain itu, individu mengamati keberhasilan orang lain yang kemampuannya sama dengannya dan nasihat dari orang-orang terdekat. Serta semangat yang tinggi untuk mencapai prestasi belajar yang telah di targetkan.

Kategorisasi dukungan sosial keluarga menunjukan bahwa sebanyak 32 subjek penelitian atau 51,61\% dari 62 subjek penelitian memiliki dukungan sosial keluarga yang sedang. Sedangkan 29 subjek penelitian atau 46,77\% dari 62 subjek penelitian memiliki dukungan sosial keluarga yang tinggi. Hal ini menunjukkan bahwa pada umumnya subjek mendapatkan dukungan sosial yang cenderung tinggi dari keluarganya. Dukungan sosial yang cenderung tinggi dari keluarga dapat disebabkan karena individu memperoleh kehangatan, perhatian, dorongan, arahan, dan bimbingan 
dari keluarga, apabila individu yang bersangkutan mengalami kesulitan dalam belajar. Pemenuhan kebutuhan fasilitas belajar yang mendukung kegiatan individu dan adanya pujian apabila individu yang bersangkutan memperoleh prestasi.

Efikasi diri dan dukungan sosial keluarga memberikan sumbangan efektif terhadap self regulated learning atau koefisien determinan $\left(\mathrm{r}^{2}\right)$ sebesar 0,700 artinya yaitu terdapat $70 \%$ pengaruh efikasi diri dan dukungan sosial keluarga terhadap self regulated learning. Hal ini berarti terdapat $30 \%$ variabel lain selain efikasi diri dan dukungan sosial keluarga yang mempengaruhi self regulated learning selain efikasi diri dan dukungan sosial keluarga.

\section{Simpulan}

Berdasarkan hasil penelitian maka dapat diambil kesimpulan sebagai berikut : Ada hubungan positif yang sangat signifikan antara efikasi diri dan dukungan sosial keluarga dengan self regulated learning. Ada hubungan positif yang sangat signifikan antara efikasi diri dengan self regulated learning. Semakin tinggi efikasi diri, maka semakin tinggi self regulated learning. Semakin rendah efikasi diri maka semakin rendah self regulated learning. Ada hubungan positif yang sangat signifikan antara dukungan sosial keluarga dengan self regulated learning. Semakin tinggi dukungan sosial keluarga, maka semakin tinggi self regulated learning. Semakin rendah dukungan sosial keluarga maka semakin rendah self regulated learning.

Sumbangan efektif variabel efikasi diri dan dukungan sosial keluarga terhadap self regulated learning sebesar 70\%. Pengaruh variabel efikasi diri sebesar 68,5\% sedangkan variabel dukungan sosial keluarga sebesar $1,5 \%$. Hal ini berarti terdapat $30 \%$ variabel lain, diluar variabel efikasi diri dan dukungan sosial keluarga yang mempengaruhi self regulated learning. Hasil kategorisasi menunjukkan 80,65\% subjek memiliki self regulated learning berada pada kategori sedang, 67,74\% subjek memiliki efikasi diri berada pada kategori sedang dan 51,61\% subjek memiliki dukungan sosial keluarga pada kategori sedang.

\section{Daftar Pustaka}

Alwisol. (2005). Psikologi Kepribadian. Malang : UMM Press

Bandura, A. (1997). Self Efficacy: The Exercise of Control. New York: Freeman and Company. 
Baron. R.A. \& Byrne. D. (2003). Psikologi Sosial Edisi Kesepuluh Jilid 2. Jakarta: Erlangga.

Hurlock, E.B. (2001). Psikologi Perkembangan Suatu Pendekatan Sepanjang Rentang Kehidupan. Jakarta : Erlangga

Johnson. D. W, Johnson. F. (1991) Joining Together. Group Theory and Group Skill. Fourth Edition. Englewood Cliffts. Prentice Hall Inc

Santrock, J.W. (2007). Psikologi Pendidikan. Edisi Kedua. Jakarta : Prenada Media Group

Smet. B.( 1994). Psikologi Kesehatan. Jakarta: PT. Grasindo

Zimmerman, B.J. (1990). Self Regulated Learning and Academic Achievement: An Overview. Educational Psychologist. 25(1), 3-17. Lawrence Erlbaum Associates. 